Prawo Kanoniczne $56(2013) \mathrm{nr} 1$

KS. WOJCIECH NECEL TCHR

\title{
KURIA RZYMSKA WOBEC DOBRA DUCHOWEGO MIGRUJĄCYCH
}

Treść: Wstęp. - 1. Proces budowania struktur ogólnokościelnych. - 1.1. W okresie przed wydaniem konstytucji Exsul Familia. - 1.2. Exsul Familia wobec konieczności zorganizowania duszpasterstwa migrantów. -2 . Instytucje centralne odpowiedzialne za duszpasterstwo ludzi w drodze wg instrukcji Kongregacji Biskupów De pastorali migratorum cura z 1969 roku. - 3. Powołanie Papieskiej Komisji Duszpasterstwa Migrantów i Turystów w motu proprio Pawła VI Apostolicae caritatis z 19.03.1970 roku. - 4. Konstytucja apostolska Jana Pawła II Pastor Bonus z 28.06.1988 roku w trosce o migrujących. - 4.1. Powołanie Papieskiej Rady ds. Duszpasterstwa Migrantów i Podróżujących. - 4.2. Rola Sekretariatu Stanu wobec potrzeb duchowych ludzi w drodze. - 4.3. Specyfika zadań Kongregacji wobec migrujących. - 4.4. Papieskie Rady a opieka nad poszczególnymi kategoriami migrantów. - Zakończenie.

\section{Wstęp}

Kościół od zarania swoich dziejów pochylał się z duszpasterską troską nad wszystkimi migrantami. Wędrowcom i pielgrzymom, wypędzonym i uchodźcom wytrwale i cierpliwie towarzyszyli pasterze Kościoła $^{1}$. W 60 rocznicę opublikowania konstytucji apostolskiej Piusa XII Exsul Familia², w kontekście współczesnych ruchów migra-

1 Papieska Rada ds. DuszPasterstwa Migrantów i Podróżujących, Instrukcja Erga migrantes caritas Christi (dalej EMCC), Lublin 2008, nr 14.

2 PIus XII, Konstytucja apostolska Exsul Familia (dalej EF), Studia Polonijne 4(1981), s. 15-58; EMCC 20: „Odczuwało się potrzebę dokumentu, który by zebrał dziedzictwo poprzednich przepisów i zaleceń, oraz ukierunkował ku duszpasterstwu organicznemu. Pożyteczną na nią odpowiedzią jest konstytucja apostolska Exsul Familia opublikowana 1 sierpnia 1952 roku przez Piusa XII, którą uważa się za magna carta myśli Kościoła o migracjach. Jest to pierwszy oficjalny dokument Stolicy Apostolskiej, który z punktu widzenia historycznego i kanonicznego kreśli w sposób 
cyjnych warto przeanalizować na nowo poszczególne segmenty apostolatu dla migrujących, z migrującymi i wśród nich. Jedną z części tego apostolatu, która wyrasta $\mathrm{z}$ wieloaspektowej obecności Kościoła wśród ludzi w drodze, są zadania Kurii Rzymskiej. Można je rozpatrywać i systematyzować w kontekście historycznym, ale również wobec poszczególnych kategorii wiernych tworzących współczesne i coraz bardziej globalizujące się zjawisko ludzi w drodze. Tak podjęte tematy zakotwiczone są w dojrzewającym na przestrzeni dziejów Kościoła przeświadczeniu, że działalność pastoralna misjonarzy migrantów, proboszczów parafii terytorialnej na rzecz przybyszów i ordynariuszy miejsca na rzecz migrantów, winna być strukturalnie zorganizowana i koordynowana na szczeblu Kurii Rzymskiej. Wobec wciąż intensyfikującego się natężenia ruchów migracyjnych, poszczególne organa Stolicy Apostolskiej poprzez swoje inicjatywy wciąż na nowo inicjują i stymulują wieloaspektowe zatroskanie o wiernych migrujących, a także migrantów chrześcijan niekatolików, wiernych innych religii oraz ateistów i niewierzących.

Szczególnym świadectwem zainteresowania się ludźmi w drodze jest pierwsza część konstytucji apostolskiej Piusa XII Exsul Familia. Uwzględniając okresy pontyfikatów swoich poprzedników, Pius XII chronologicznie i bardzo szczegółowo przedstawił panoramę inicjatyw Stolicy Apostolskiej wobec migrantów, a także wskazał ważniejsze świadectwa duszpasterskiej troski Kościoła lokalnego o ludzi w drodze. Obowiązująca konstytucja apostolska Jana Pawła II Pastor Bonus z 28 czerwca 1988 roku $^{3} \mathrm{w}$ proponowanym studium jest między inny-

globalny i systematyczny duszpasterstwo dla migrantów. W konstytucji po szerokiej analizie historycznej następuje bowiem część ściśle normatywna, mocno wyartykułowana. Zostaje w niej potwierdzona główna odpowiedzialność lokalnego biskupa diecezjalnego za troskę duszpasterską o migrantów, choć organizacja w tym względzie jest jeszcze powierzona Kongregacji Konsystorialnej"; por. W. NeCEL, Pastoralna postawa wobec potrzeb duchowych migrantów w świetle wybranych dokumentów Kościoła. Refleksja w 50. rocznicę ogtoszenia przez Piusa XII konstytucji apostolskiej „Exsul Familia”, Collectanea Theologica 73(2003) nr 3, s. 195-197.

3 Jan Pawee II, Konstytucja apostolska Pastor Bonus (dalej PB), w: Ustrój hierarchiczny Kościoła (red. M. Sitarz, W. Kacprzyk). Lublin 2006, s. 217-257. 
mi wyrazem współczesnej troski o ludzi w drodze i pozwala prześledzić zakres zobowiązań poszczególnych Dykasterii Kurii Rzymskiej wobec fenomenu migracji człowieka na przełomie XX i XXI wieku.

\section{Proces budowania struktur ogólnokościelnych}

Wobec wzrastającego natężenia ruchów migracyjnych zarówno inicjatywy duszpasterskie dla dobra duchowego ludzi w drodze w poszczególnych Kościołach lokalnych, jak i te podejmowane i popierane przez Stolicę Apostolską, domagały się nie tylko usystematyzowania, ale i oparcia o adekwatne oraz sprawne struktury duszpasterskie.

\subsection{W okresie przed wydaniem konstytucji Exsul Familia}

Problem ogólnokościelnej organizacji duszpasterstwa migrantów jako wyraz troski całego Kościoła o ich dobro duchowe dostrzegał już G.B Scalabrini. W petycji Pro emigrantis catholicis, skierowanej do Stolicy Apostolskiej, zaproponował powołanie centralnego organu (kongregacji bądź komisji) zajmującego się problematyką apostolstwa wśród emigrantów katolików ${ }^{4}$. Zdaniem pomysłodawcy kongregacja ta miałaby zapobiegać rodzącym się napięciom nacjonalistycznym w środowiskach imigracyjnych oraz powstrzymywać narastające podziały imigrantów katolików według kryteriów narodowościowych i językowych $^{5}$. Efektem zabiegów J.B. Scalabriniego było utworzenie przez Piusa X w roku 1912 przy Kongregacji Konsystorialnej novum officium seu sectionem (Biura ds. Problemów Migracji) do duszpasterstwa migrantów, którego zadaniem było monitorowanie potrzeb duchowych migrantów Kościoła łacińskiego oraz zaradzanie ich duszpasterskim potrzebom według możliwości organizacyjnych i personalnych. Urząd ten, przy zachowaniu kompetencji Kongregacji Rozkrzewiania Wiary, miał również nadzorować opiekę duszpasterską nad migrantami ob-

${ }^{4}$ Por. EMCC 31.

5 G.B. Scalabrini, Memoriale Pro emigrantibus catholicis z 4.05.1905, w: S. Tomasi, G. Rosoli, Scalabrini e le migrazioni moderne. Scritti e carteggi, Torino 1997, s. 233 . 
rządków wschodnich ${ }^{6}$. Już po śmierci bp. G. Scalabriniego Kongregacja Konsystorialna listem z dnia 6 grudnia 1914 roku podjęła się realizacji innej jego inicjatywy. Celem uwrażliwienia na potrzeby duchowe emigrantów ustanowiono w Kościele włoskim Dzień Migran$\mathrm{ta}^{7}$, a realizując idee założyciela skalabrynianów papież Benedykt XV powołał prałata personalnego dla księży kierowanych do duszpasterstwa włoskich migrantów ${ }^{8}$.

Po II wojnie światowej troska Kościoła o adekwatną opiekę religijną i społeczną nad wszystkimi kategoriami ludzi w drodze przybierała, zarówno w diecezjach, jak i szczeblu centralnym Kościoła powszechnego, coraz bardziej instytucjonalny charakter. W 1946 roku Pius XII powołał przy Sekretariacie Stanu Ufficio Migrazione, składający się z dwóch sekcji: migracji dobrowolnej i migracji przymusowej, a do powstałego w Genewie Urzędu migracyjnego został wysłany stały przedstawiciel Stolicy Apostolskiej ${ }^{9}$.

\subsection{Exsul Familia wobec konieczności zorganizowania duszpasterstwa migrantów}

Wobec dynamiki zjawiska migracji w połowie XX wieku i narastającej konieczności wypracowywania właściwych metod duszpasterstwa migrantów, „odczuwało się potrzebę dokumentu, który by zebrał dziedzictwo poprzednich przepisów i zaleceń oraz ukierunkował je ku współczesnemu duszpasterstwu organicznemu". Na tak zarysowane potrzeby odpowiedział Pius XII w konstytucji apostolskiej Exsul Familia, opublikowanej 1 sierpnia 1952 roku, którą i dzisiaj w litera-

${ }^{6}$ Pius X, Motu proprio Cum omnes cathlicos, AAS 4(1912), s. 527: "Huius Officii partes erunt, quarere et parare omnia, quaecumquae opus sint, ut in iis quae ad salutem animarum pertinet, emigrantium latini ritus melior conditi fiat, salvo tamen iure Sacrae Congregationis Fidei Propagandae in emigrantes ritus orientalis, quibus eadem Congregatio pro suo instituto opportune consulat".

7 S.C. Consistorialis, Litterae circulars ad R.mos Ordinaris Italiae, de spirituali emigratorum cura, 6 Decembris 1914, AAS 6(1914), s. 699-701.

${ }^{8}$ Notificatione della Consistoriale del 23 ottobre 1920, AAS 12(1920), s. 534-535.

${ }^{9}$ L'attivita della Santa Sede: dal 15 Dicembre 1946 al 15 Dicembre 1947, Tipographia Poliglotta Vaticana, s. 125-135. 
turze przedmiotu określa się jako magna carta troski Kościoła o migrujących ${ }^{10}$. Aklamacja, którą Pius XII rozpoczyna konstytucję Exsul Familia, już na początku I części dokumentu wskazuje na zakres odpowiedzialności Kościoła za dobro duchowe migrantów. Kościół ,jak Matka, kierując się żarliwą miłością dusz, starał się wypełnić zadanie powszechnego planu zbawczego, powierzonego mu przez Chrystusa. Prowadził więc duszpasterstwo również nad cudzoziemcami, przybyszami, wygnańcami i wszystkimi emigrantami. Czynił to za pośrednictwem kapłanów, którzy gorliwie umacniali w wierze wyznawców Chrystusa węzłami miłości przez rozdawanie łaski charyzmatów i głoszenie słowa Bożego"11. Słowa te otwierają prawno-historyczną refleksję o duszpasterskiej trosce Kościoła o dobro duchowe emigrantów i przygotowują do lektury II części konstytucji, obejmującej strukturalne rozwiązania duszpasterskiej służby tak na szczeblu Kurii Rzymskiej, jak i w Kościołach diecezjalnych wobec migrujących oraz ich potomków.

Według Exsul Familia w organizacji opieki duszpasterskiej nad ludźmi w drodze ważną rolę odegrali sami migranci. Pius XII zauważył, że w historii Kościoła w wielu przypadkach to oni sami byli protagonistami specjalnej troski duszpasterskiej i podkreślił: ,ile (...) pożytku przyniosły (...) parafie, erygowane częstokroć na życzenie cudzoziemców, zarówno diecezjom jak i duszom, wszyscy o tym doskonale wiedzą i wyrażają im należyte uznanie"12. Jednak specyficzna sytuacja egzystencjalna wierzącego migrującego z połowy XX wieku domagała się nie tylko uznania, ale wypracowania właściwych struktur duszpasterstwa specjalnego. Dlatego też „w konstytucji po szerokiej analizie historycznej następuje (...) część ściśle normatywna, mocno wyartykułowana”, ${ }^{13}$, zatytułowana „Normy opieki duszpasterskiej nad emigrantami”. Podzielona jest na sześć rozdziałów. Pierwszy z nich zawiera zapis, że w imieniu Stolicy Apostolskiej za duszpasterstwo

${ }^{10}$ EMCC 20; zob. W. NeCEL, Pastoralna postawa wobec potrzeb duchowych migrantów..., s. 193-197.

${ }^{11}$ EF, s. 16.

${ }^{12}$ Tamże, s. 18.

${ }^{13}$ EMCC 20. 
migrantów odpowiedzialna w sensie wykonawczym była Kongregacja Konsystorialna. Do niej należało i jej wyłącznie przysługiwało , prawo do badania i przygotowywania wszystkiego, co przyczynia się do duchowego dobra emigrantów obrządku łacińskiego" oraz emigrantów obrządków wschodnich ${ }^{14}$. Istotnym jej zadaniem była troska o kapłanów, którzy podejmowali pracę w duszpasterstwie migracyjnym. Od Kongregacji kapłani ci otrzymywali między innymi: pozwolenie na wyjazd do pracy wśród migrantów w krajach zamorskich, zezwolenie na inkardynację do diecezji, w której będą sprawowali duszpasterstwo na rzecz migrantów oraz zgodę na ewentualne przejście do pracy $\mathrm{w}$ duszpasterstwie emigracyjnym $\mathrm{w}$ innym kraju ${ }^{15}$. Dla misjonarzy migrantów w danym kraju Kongregacja powoływała „dyrektora misjonarzy emigrantów danej narodowości lub języka" "16. W tak zakreślonym dziele Kongregacja Konsystorialna winna współpracować odpowiednio z Kongregacją dla Kościołów Wschodnich oraz Kongregacją Rozkrzewiania Wiary ${ }^{17}$.

Rozdział II poświęcony jest urzędowi Delegata ds. Emigracji, który został powołany przez Piusa XII przy Kongregacji Konsystorialnej. Do zadań Delegata, jako zwierzchnika misjonarzy migrantów i kapelanów morskich oraz ich dyrektorów narodowych, należało wspieranie ,wysiłków zmierzających ku dobru wiernych przebywających na emigracji, zwłaszcza ich dobru duchowemu". Zadanie to mieli podejmować bez względu na język, pochodzenie, narodowość czy obrządek migrantów. Delegat miał służyć pomocą wszystkim instytucjom i osobom prywatnym zatroskanym o dobro duchowe migrantów oraz wspierać podejmowane w tym celu inicjatywy w Kościołach lokalnych. On też brał czynny udział w procesie nominacji misjonarzy migrantów i w przygotowaniach obchodów corocznego Ogólnokościelnego Dnia Emigranta ${ }^{18}$. Obok Delegata ds. Emigracji w Exsul Familia Pius XII powołał przy Kongregacji Konsystorialnej Najwyższą Radę

\footnotetext{
${ }^{14}$ EF I, 1 par. 1-2.

${ }^{15}$ Tamże, art. I, 1-8.

${ }^{16}$ Tamże, art. I, 2 par. $1-8$ par. 3 .

${ }^{17}$ Tamże, art. I, 1 par. 1.

${ }^{18}$ Tamże, art. II, 9-17.
} 
ds. Emigracji ${ }^{19}$ oraz samodzielną Wyższą Radę ds. Migracji ${ }^{20}$ i Międzynarodowy Sekretariat Generalny dla kierowania Dziełami Apostolstwa Morza ${ }^{21}$. Kolejny rozdział II części konstytucji poświęcony jest regulacjom dotyczącym Dyrektorów Misjonarzy Migrantów oraz Dyrektorów Kapelanów Morskich, a także regulacjom dotyczącym samych misjonarzy emigrantów oraz kapelanów morskich ${ }^{22}$.

Pozostałe dwa rozdziały części II konstytucji Exsul Familia dotyczą duszpasterstwa na rzecz włoskich emigrantów. Zamieszczenie ich w konstytucji apostolskiej skierowanej do całego Kościoła powszechnego było jedną z przyczyn nieprzychylnych ocen całego przesłania Piusa XII zawartego w Exsul Familia i nieprzyjęcia go przez niektóre Episkopaty krajowe. Wysuwano obawy, że stosowanie sztywnych norm Exsul Familia w krajach wieloetnicznych naruszałoby jedność duszpasterstwa tamtejszych diecezji. Ostatecznie „biskupi (...) nie chcieli dopuścić do powstania w ich krajach ponaddiecezjalnej organizacji specjalnego duszpasterstwa migrantów, lękając się jego utworzenia, a w konsekwencji opóźniania procesu integracji”23. Sukcesywnie w komentarzach pojawiały się kolejne uwagi i pomimo zalet konstytucji często akcentowano tylko jej merytoryczne braki ${ }^{24}$. Podkreślano, że duszpasterstwo migrantów było bardzo zcentralizowane i zależne od Stolicy Apostolskiej ${ }^{25}$. Powołany przez Piusa XII Dyrektor Misjonarzy Migrantów w podejmowanych inicjatywach i w swoim działa-

${ }^{19}$ Tamże, art. I, 7; por. G. Ferretto, In Constitutionem apostolicam „Exsul Familia” animadversiones, Monitor Ecclesiasticus 78(1953), s. 368.

${ }^{20}$ EF I 7 par. 2.

${ }^{21}$ Tamże, art. IV 32-40.

${ }^{22}$ EF III, 18-31.

${ }^{23}$ J. BaKalarz, Podstawowe dokumenty Kościoła w sprawie opieki duszpasterskiej nad migrantami, Studia Polonijne 4(1981), s. 7-8.

${ }^{24}$ Por. V. DE PAolis, De cura pastorali migratorium, Periodica 70(1981), s. 150: "Sed, decursu non longi temporis, limites etiam opsius Constitutionis in lucem venerunt, et ideo nonnullae obiectiones contra eius legislationis motae sunt".

${ }^{25}$ Tamże, s. 151: “(...) potius concentralizata apud Curiam Romanam. Ordinari locorum quamquem responsabilitatem directam et habeant immediatam de cura pastorali, indigent tamen licentia ipsius Sacrae Congregationis Consistoriales sive ad erigendas paroecias personales sive ad erigendas missiones cum cura animarum". 
niu był bardzo ściśle podporządkowany Kurii Rzymskiej ${ }^{26}$. Zarzucano również, że cała konstytucja ma „koloryt krajów europejskich” i nie bierze dostatecznie pod uwagę sytuacji krajów imigracyjnych zamorskich. Wskazywano, że sub aspecto iuridico, peregrino et advenae assimilis fit. Cura specifica pastorali migratorum erga extedebatur tantum usque ad secundum generationem ${ }^{27}$. Troska o dobro duchowe migrantów przedstawiana była jako troska samych tylko duszpasterzy migrantów, a nie jako zadanie duszpasterskie dla wszystkich duszpasterzy i całego Kościoła ${ }^{28}$. Kolejny zarzut wobec konstytucji Piusa XII podkreślał, że Exsul Familia zajmowała się migracją tylko pod względem duszpasterskim, a factum migratorum non exsaminatur in tota sua complexsitate; respicitur tantum sub uno aspektu, id est curie spirituals. Etami quomodo apta cura pastorali fini potest, si ignoratur ipsum facum in tota sua amplitudine ${ }^{29}$.

Jednak pomimo wielu zarzutów konstytucja Exsul Familia „odegrała (...) ważną rolę ideową w dziedzinie ochrony praw migrantów oraz przyczyniła się do rozwoju opieki nad nimi w ramach diecezjalnej organizacji duszpasterskiej"30. Świadectwo troski Kościoła o migrujących, ujęte w I części konstytucji, jest ,swoistym pomnikiem działalności Kościoła na rzecz migrantów, a równocześnie stanowi doktrynalną podbudowę niektórych praw migrantów, zwłaszcza ich prawa do specjalnej opieki duszpasterskiej. Konstytucja nakazuje otoczyć migrantów taką opieką duchową, która odpowiada ich potrzebom i nie jest mniejsza od tej, z jakiej korzystają inni wierni w swej diecezji. Aprobuje ona w ten sposób duszpasterstwo emigracyjne i nadaje mu oficjalnie prawo obywatelstwa w Kościele"31. Trzeba pamiętać, że Exsul

${ }^{26}$ Tamże, s. 151: „(...) ipsi Missionarii Directorem habend ab ipsa Sede Apostolich constitutum, cui referre debet etiam de ipsis missionaries et eorum vita".

${ }^{27}$ Tamże.

${ }^{28}$ Per un aggiornamento dell'attuale ordinamento giuridico dell'assistenza spirituale agli emigrati, Studii Emigrazioni 2(1966), s. 267.

${ }^{29}$ V. DE PAOLIS, dz. cyt., s. 151; por. W. NeCEL, Il charisma della Società di Cristo per gli emigrati polacchi, Poznań-Rzym, 1988, s. 164-165.

${ }^{30}$ J. BAKalarz, dz. cyt., s. 8.

${ }^{31}$ Tamże, s. 7. 
Familia jest pierwszym oficjalnym dokumentem Stolicy Apostolskiej, „który z punktu widzenia historycznego i kanonicznego kreśli w sposób globalny i systematyczny duszpasterstwo dla migrantów"32.

Doświadczenie duszpasterstwa migracyjnego Kościoła, przywołane w konstytucji Exsul Familia Piusa XII oraz jej krytyka, spowodowały, że problematyka duszpasterstwa migrantów przewijała się w pracach Soboru Watykańskiego II już od momentu jego zwołania aż po eklezjologię communio Konstytucji dogmatycznej o Kościele Lumen gentium, po inkulturację Ewangelii według Konstytucji duszpasterskiej o Kościele w świecie współczesnym Gaudium et spes i po wskazania Dekretu o pasterskich zadaniach biskupów w Kościele Chrystus Dominus.

\section{Instytucje centralne odpowiedzialne za duszpasterstwo ludzi w drodze wg instrukcji Kongregacji Biskupów De pastorali migratorum cura z 1969 roku}

Wykorzystując troskę o dobro duchowe ludzi w drodze, która ujawniła się w czasie obrad Soboru Watykańskiego II, papież Paweł VI w motu proprio Pastoralis migratorum cura z dnia 15.08.1969 roku $^{33}$ zapowiedział nowe organiczne usystematyzowanie duszpasterskiej opieki Kościoła nad migrującymi. Kierując się zróżnicowaniem kulturowym Ludu Bożego, na które wskazał w motu proprio Paweł VI, i zgodnie z jego zapowiedzią, kilka dni później, 22.08.1969 roku Kongregacja Biskupów wydała instrukcję De pastorali migratorum cura ${ }^{34}$. W proponowanych rozwiązaniach kanoniczno-duszpasterskich do Kongregacji Biskupów należało „kierowanie, zarządzanie, koordynowanie i prowadzenie tego wszystkiego, co dotyczy opieki duchowej nad wiernymi obrządku łacińskiego, którzy dokądkolwiek emigrują". Miała ona porozumiewać się „z Kongregacją Kościołów Wschodnich

\footnotetext{
${ }^{32}$ EMCC 20.

${ }^{33}$ Pawee VI, Motu proprio Pastoralis migratorum cura, Studia Polonijne 4(1981), s. $59-60$.

${ }^{34}$ Kongregacja Biskupów, Instrukcja De pastorali migratorum cura (dalej DPMC), Studia Polonijne 4(1981), s. 61-86.
} 
i Kongregacją Ewangelizowania Narodów, gdy idzie o tereny podległe jednej z tych Kongregacji”. W wypełnianiu powierzonych zadań Kongregacja nie mogła naruszać obowiązków i władzy ordynariuszów miejsca w zakresie duszpasterskim ${ }^{35}$.

Zgodnie z konstytucją apostolską Pawła VI Regimine Ecclesiae Universae z 15.08.1967 roku, w De pastorali migratorum cura przydzielono Kongregacji Biskupów „Rady i Sekretariaty: dla Emigracji, dla dzieł Apostolatu morskiego, lotniczego i ludów koczowniczych"36. W realizacji tych zadań Kongregacja Biskupów winna współpracować w odpowiednim zakresie z Kongregacją ds. Zakonnych i Instytutów Świeckich oraz z sekretariatami ds. jedności chrześcijan, niechrześcijan i niewierzących oraz brać udział w tych wszystkich poczynaniach „które wydają się pożyteczne dla grup migrantów każdej wiary”37.

Kongregacja Biskupów w trosce o dobro duchowe migrantów korzystała również z pomocy powołanego wcześniej Urzędu ds. Migracyjnych $^{38}$ oraz była wspomagana przez utworzoną przez instrukcję $D e$ pastorali migratorum cura Radę Wyższą ds. Migracji, której pracom przewodniczył każdorazowy sekretarz Kongregacji ${ }^{39}$. Do zadań, które instrukcja wyznaczyła Radzie, należało analizowanie problemów duszpasterstwa migrantów w świetle nauczania Soboru Watykańskiego II oraz formułowanie wniosków dotyczących opieki nad ludźmi w drodze i przekazywanie ich celem realizacji Kongregacji Biskupów ${ }^{40}$.

\section{Powołanie Papieskiej Komisji Duszpasterstwa Migrantów i Turystów w motu proprio Pawła VI Apostolicae caritatis z 19.03.1970 roku}

Dalszy rozwój organów Stolicy Apostolskiej mających na celu dobro duchowe wszystkich migrujących możemy obserwować w motu

\footnotetext{
${ }^{35}$ DPMC 16 par. 1.

${ }^{36}$ PAWEe VI, Konstytucja apostolska Regimini Ecclesiae Universae, w: Ustrój hierarchiczny Kościoła (red. M. Sitarz, W. Kacprzyk). Lublin 2006, nr 52.

${ }^{37}$ DPMC 16 par. 5-6.

${ }^{38}$ Tamże, art. 18 par. $1-2$.

${ }^{39}$ Tamże, art. 19.

${ }^{40}$ Tamże, art. 20-21.
} 
proprio Pawła VI Apostolicae caritatis z 19 marca 1970 roku $^{41}$. Ojciec św. przywołał całe kościelne dziedzictwo troski o migrantów zawarte w Exsul Familia oraz już po jej ogłoszeniu. W 1953 roku Pius XII Kongregacji Konsystorialnej podporządkował Dzieło Apostolstwa Nieba lub Podróży Powietrznej, opiekujące się wiernymi zatrudnionymi w portach lotniczych lub samolotach, a także korzystających z podróży powietrznych ${ }^{42}$. Paweł VI idąc za wskazaniami soborowego dekretu Christus Dominus ${ }^{43}$, przy wspomnianej Kongregacji w 1965 roku powołał Międzynarodowy Sekretariat ds. Apostolstwa Ludów Koczowniczych, opiekujący się tymi wiernymi, którzy nie mają stałego zamieszkania, w tym i pracownikami cyrków ${ }^{44}$.

Jednak głównym zadaniem motu proprio Apostolicae caritatis była dalsza centralizacja organów Stolicy Apostolskiej odpowiedzialnych za ludzi w drodze. W tym celu w zależności od Kongregacji Biskupów Paweł VI powołał Papieską Komisję ds. Duszpasterstwa Migrantów i Turystów (Pontificia Commissione per le Migrazioni e il Turismo) ${ }^{45}$. Papież podkreślił, że w przeszłości Biskupi Rzymscy, wczuwając się w sytuację egzystencjalną i duchową migrujących, starali się ,wedle możliwości" zaradzać potrzebom wszystkich kategorii ludzi w drodze, a cały „Kościół katolicki powodowany apostolską miłością, kierował swoją troskliwą opiekę ku dostarczeniu swoim dzieciom tych środków, zwłaszcza duchowych, które zdawały się postulować szczególne okoliczności, dotyczące ludzi, rzeczy i czasów"46. Jednak w ostatnim czasie ze względu na łatwość podróżowania, wielokierunkowość migracji oraz prognozowane natężenie ruchów ludności „trzeba zwrócić uwagę nie tylko na tych, którzy mieszkają w ustalonych granicach parafii (...) lecz także na tych, którzy z własnej woli lub na skutek jakiejś ko-

\footnotetext{
${ }^{41}$ PAWE⿺ VI, Motu proprio Apostolicae caritatis (dalej AC), Studia Polonijne 4(1981), s. 87-89.

${ }^{42}$ Tamże, s. 88.

${ }^{43} \mathrm{CD} 18$.

${ }^{44}$ AC s. 87-89.

45 Tamże, s. 88.

46 Tamże, s. 87.
} 
nieczności opuszczają miejsce zamieszkania"47. Waga problemu troski duchowej o migrujących zdaniem Pawła VI wymagała jednak dalszej koordynacji i scalania wysiłków oraz poddanie ich jednemu kierownictwu. Dlatego też przy Kongregacji Biskupów papież powołał Papieską Komisję ds. Duszpasterstwa Migrantów i Turystów, obejmującą między innymi dzieła: apostolat migrantów, uchodźców i wypędzonych, apostolstwo ludzi morza, apostolstwo podróży powietrznych, apostolstwo koczowników, opiekę nad turystami, pielgrzymami i studentami zagranicznymi. Zgodnie z decyzją Pawła VI funkcje przewodniczącego Komisji pełnił każdorazowy Kardynał Prefekt Kongregacji Biskupów, wspierany przez sekretarza Komisji. Powołana Papieska Komisja, strukturalnie zależna od Kongregacji, cieszyła się jednak „pewną autonomią w załatwianiu swoich spraw”. Jej zadaniem było analizowanie wspólnie z Krajowymi Konferencjami Biskupów spraw związanych z wszystkimi kategoriami ludzi w drodze oraz podejmowanie decyzji dla dobra duchowego migrantów, które poszczególne Konferencje Episkopatów będą wprowadzały na swoim terenie ${ }^{48}$.

\section{Konstytucja apostolska Jana Pawła II Pastor Bonus z 28.06.1988 roku w trosce o migrujących}

„Miłość Chrystusa wobec migrantów” pobudza również Kurię Rzymską, która jako zespół Dykasterii i Instytucji świadczy ,pomoc biskupowi rzymskiemu w wykonywaniu przez niego najwyższej posługi pasterskiej dla dobra i w służbie Kościoła powszechnego i Kościołów partykularnych, przez co umacnia się jedność wiary i wspólnota Ludu Bożego, a także ożywia się misja właściwa Kościołowi w świecie"49. Kierując się tym przesłaniem Jan Paweł II w konstytucji apostolskiej Pastor Bonus z dnia 28.06.1988 roku dostosował do aktualnych potrzeb struktury, organizację pracy i odpowiedzialność poszczególnych organów Kurii Rzymskiej. Sekretariat Stanu (podzielony na dwie sekcje: do spraw ogólnych i do spraw relacji z poszczególnymi pań-

\footnotetext{
${ }^{47}$ Tamże.

${ }^{48}$ Tamże, s. 89.

${ }^{49}$ PB 1.
} 
stwami), Kongregacje, Trybunały, Rady i Urzędy uzyskały jednakowy równorzędny status. Do nich dodano: Prefekturę Domu Papieskiego i Papieski Urząd ds. Celebracji Liturgicznych ${ }^{50}$. Warto dodać, że wcześniej, aż do początku pontyfikatu Jana Pawła II, jedynie Kongregacje Kurii Rzymskiej były inter se iuridice pares ${ }^{51}$.

We wprowadzeniu do omawianej konstytucji Jan Paweł II, uzasadniając zaproponowaną reformę, wskazywał: ,pragnąłem (...) bardziej przystosować cieszące się pewną tradycją dykasterie i urzędy Kurii Rzymskiej do pełnienia zadań, dla których zostały powołane do życia, czyli do udziału w jurysdykcyjnych i wykonawczych obowiązkach zarządzania" ${ }^{2}$. Ponadto, „biorąc pod uwagę doświadczenia ostatnich lat i fakt ujawniania przez społeczność Kościoła coraz to nowych potrzeb i wymogów, poddałem weryfikacji także kształt prawny oraz działalność instytucji słusznie nazwanych posoborowymi" ${ }^{53}$, które odtąd będą tworzyły wspólną kategorię Papieskich Rad, „ażeby działalność pasterska Kościoła skutecznie się rozwijała i odpowiednio była koordynowana, z zachowaniem koniecznej łączności z Kościołami partykularnymi" ${ }^{54}$.

Posługa duszpasterska papieża i konsekwentnie służba, jaką w jego imieniu spełnia Kuria Rzymska, w konstytucji Pastor Bonus przedstawiona jest w perspektywie kolegialności wewnątrz komunii Kościoła. W tym celu poszczególne dykasterie, „każda zgodnie z własną kompetencją, rozpatruje sprawy, które ze względu na szczególne swoje znaczenie albo z natury swojej lub przez prawo, są zarezerwowane Stolicy Apostolskiej, a także te sprawy, które przekraczają granice kompetencji poszczególnych biskupów lub ich zespołów oraz te, które zostaną im zlecone przez papieża. Inicjują poczynania dla dobra Kościoła powszechnego. (...) Wreszcie rozpatrują wszystko, co wierni - korzystając z przysługujących im uprawnień - przesyłają do Stoli-

${ }^{50}$ B. Bertagna, Giovanni Paolo II uomo di governo, LEV, p. 83-84.

${ }^{51}$ Pawel VI, Konstytucja apostolska Regimini Ecclesiae Universae, nr 1 par. 2: „Kongregacje są prawnie między sobą równe”.

${ }^{52}$ PB s. 228.

${ }^{53}$ Tamże.

${ }^{54}$ Tamże, art. 12. 
cy Apostolskiej" "55. Zachowując właściwe relacje z Kościołami partykularnymi postrzegać trzeba, że do nich należy odpowiedzialność za duszpasterstwo terytorialne i współpracują one z poszczególnymi dykasteriami Kurii Rzymskiej. Stolica Apostolska każdorazowo podejmuje ,studium poważnych problemów obecnego wieku, ażeby działalność pasterska Kościoła skuteczniej się rozwijała i odpowiednio była koordynowana, z zachowaniem koniecznej łączności z Kościołami partykularnymi”"56. Tak zakreślona współpraca poszczególnych dykasterii Kurii podkreśla, że każda z nich winna zaangażować się w wieloaspektowe dzieło troski Kościoła o ludzi w drodze. Dlatego można powiedzieć, że wszystkie dykasterie są zaangażowane w działalność duszpasterską na rzecz migrantów i podróżujących, a przedmiot i zakres ich zainteresowania „określa przedmiot sprawy, chyba, że co innego wyraźnie zastrzeżono" $" 57$.

4.1. Powołanie Papieskiej Rady ds. Duszpasterstwa Migrantów i Podróżujących

Według konstytucji Pastor Bonus Jana Pawła II organem Stolicy Apostolskiej, powołanym do interesowania się i rozwijania opieki duszpasterskiej nad migrantami i podróżującymi oraz jej koordynowania w sensie stricto jest Papieska Rada ds. Duszpasterstwa Migrantów i Podróżujących (Pontificium Consilium de Spirituali Migrantium adque Itinerantium Cura). Jako spadkobierczyni Papieskiej Komisji ds. Duszpasterstwa Migrantów i Turystów, obejmuje ona ,pasterską troską Kościoła szczególne potrzeby tych, których zmuszono do opuszczenia ziemi ojczystej albo zostali całkowicie pozbawieni ojczyzny" oraz „studiuje wszystkie związane z tym problemy"58 z uwzględnieniem szczegółowo rozpisanych kompetencji w art. 150 konstytucji. Jan Paweł II nie tylko zmienił nazwę organu Stolicy Apostolskiej zajmującego się troską o ludzi w drodze, ale przyrównując go do innych

\footnotetext{
${ }^{55}$ Tamże, art. 13.

${ }^{56}$ Tamże.

${ }^{57}$ Tamże, art.14.

${ }^{58}$ Tamże, art. 149.
} 
dykasterii podniósł jego rangę i znaczenie ${ }^{59}$. Papieska Rada obejmując pastoralną troską ludzi w drodze (gente in movimento) ma za zadanie podejmować wszelkie działania bezpośrednie i pośrednie animujące Kościoły partykularne do posługi na rzecz migrantów i podróżujących, „aby lud chrześcijański, zwłaszcza z okazji Światowego Dnia Emigranta i Wygnańca, uświadomił sobie ich potrzeby i dał wyraz braterskiej troski" 60 .

Osoby objęte specjalną opieką duszpasterską Rady to w szczególności ci wierni, których zmuszono do opuszczenia ziemi ojczystej lub nie mają żadnej swojej trwałej ojczyzny ${ }^{61}$, a więc uciekinierzy, wypędzeni, bezpaństwowcy oraz koczownicy i cyrkowcy ${ }^{62}$. Swoimi kompetencjami Rada obejmuje również marynarzy i rybaków oraz pracujących w portach i podróżujący na statkach ${ }^{63}$, a także lotników i pracowników cywilnych portów lotniczych oraz korzystających z linii lotniczych ${ }^{64}$, pielgrzymów, studentów i turystów oraz tych wszystkich, którzy znajdują się przez dłuższy czas poza miejscem zamieszkania $^{65}$.

Specyfika troski pastoralnej o ludzi w drodze Papieskiej Rady ds. Duszpasterstwa Migrantów i Podróżujących, rozpisana jest w instrukcji z 3 maja 2004 roku Erga migrantes caritas Christi. Instrukcja ta składa się z wprowadzenia i z czterech części zatytułowanych kolejno: „Migracje, znak czasu i troska Kościoła”, „Migranci i duszpasterstwo przyjmowania”, „Operatorzy duszpasterstwa komunii w Kościołach macierzystych i przebywania”, „Struktury duszpasterstwa misyjnego” oraz zakończenia. Integralną częścią instrukcji jest kolejny rozdział za-

\footnotetext{
${ }^{59}$ Tamże, art. 2 par. 2: „Dykasterie są prawnie między sobą równe”.

${ }^{60}$ Tamże, art. 150 par. 4. Ze względu na tłumaczenie, warto w tym miejscu przytoczyć tekst oryginalny tego paragrafu: „Si sforza affinchè il popolo cristiano, soprattutto in occasione della celebrazione della giornata mondiale per i migranti i profughi, acquisti coscienza della loro necessità e manifesti efficamente la sua solidarietà nei loro confronti".

${ }^{61}$ Tamże, art. 149.

${ }^{62}$ Tamże, art. 150 par. 1.

${ }^{63}$ Tamże, art. 150 par. 2.

${ }^{64}$ Tamże, art. 150 par. 3.

${ }^{65}$ Tamże, art.151.
} 
tytułowany: „Przepisy prawno-duszpasterskie”, który składa się z 22 artykułów uszeregowanych w 6 kolejnych rozdziałach. Ostatni z nich zakreśla obszar odpowiedzialności Papieskiej Rady. Według instrukcji winna ona zgłębiać wszystkie problemy związane z duszpasterstwem poszczególnych kategorii migrantów ${ }^{66}$, a także świadczyć pomoc w zakresie organizowania w Kościele diecezjalnym skutecznego i własnego duszpasterstwa, również przez tworzenie w razie potrzeby odpowiednich struktur duszpasterskich dla uciekinierów, wygnańców oraz migrantó $\mathrm{w}^{67}$, z zachowaniem jednak odpowiedzialności poszczególnych Kościołów oraz poszczególnych organów Stolicy Apostolskiej ${ }^{68}$. $\mathrm{Na}$ tak zakreślonym fundamencie Erga migrantes wylicza zadania Papieskiej Rady, która winna zapoznawać się z raportami dotyczącymi duszpasterstwa migrantów, przesyłanymi przez poszczególne Konferencje Episkopatu i odpowiednie struktury hierarchiczne wschodnich Kościołów katolickich. Zgodnie z kan. 34 KPK Papieska Rada może wydawać instrukcje sugerujące i wspierające działalność oraz programy dotyczące duszpasterstwa na rzecz migrantów. Zadaniem jej jest również ułatwianie wymiany informacji pomiędzy poszczególnymi Konferencjami Biskupów i właściwymi strukturami katolickich Kościołów wschodnich. Może ona też uczestniczyć w procesie przenoszenia duszpasterzy celem podejmowania apostolatu na rzecz migrantów oraz wspierać, animować i harmonizować starania organów regionalnych i kontynentalnych, działających dla dobra migrujących. Papieska Rada ma prawo zapoznawać się z sytuacją migrantów i ich duszpasterzy w poszczególnych ośrodkach duszpasterskich i zwracać uwagę na erygowanie i rozwój właściwych struktur duszpasterskich. Zadaniem Rady jest również wspieranie instytutów zakonnych oraz instytutów świeckich i stowarzyszeń życia apostolskiego, które włączają się w troskę Konferencji Episkopatów i odpowiednich struktur wschodnich Kościołów katolickich o migrujących, z zachowaniem jednak kompetencji Kongregacji ds. Instytutów Życia Konsekrowane-

\footnotetext{
${ }^{66}$ Tamże, art. 149.

${ }^{67}$ Tamże, art. 150 par. 1.

${ }^{68}$ EMCC 22 par. 1.
} 
go i Stowarzyszeń Życia Apostolskiego oraz Kongregacji dla Kościołów Wschodnich. Wspólnie z Papieską Radą ds. Popierania Jedności Chrześcijan, Papieska Rada ds. Duszpasterstwa Migrantów i Podróżujących może inicjować i popierać współpracę ekumeniczną w obszarze duszpasterstwa emigracyjnego, zaś wspólnie z Papieską Radą ds. Dialogu Międzyreligijnego wspierać i inicjować działania mające na celu nawiązywanie dialogu z migrantami innych religii ${ }^{69}$.

\subsection{Rola Sekretariatu Stanu wobec potrzeb duchowych ludzi w drodze}

Sekretariat Stanu Stolicy Apostolskiej wspomaga „papieża w wykonywaniu przez niego najwyższej posługi w Kościele"70. Służy pośrednio dobru migrantów i podróżujących poprzez dwie swoje sekcje. Pierwsza $z$ nich rozpatruje i załatwia przede wszystkim te sprawy, „które wiążą się z codzienną posługą biskupa rzymskiego"71, a również „wszystkie sprawy, które przekraczają zwyczajne kompetencje dykasterii Kurii Rzymskiej oraz innych instytucji Stolicy Apostolskiej. Utrzymuje i ożywia kontakty z poszczególnymi dykasteriami i koordynuje prace, nie naruszając jednak ich autonomii"72. W ostatnim czasie podkreśla się wymiar pastoralny posługi dyplomatycznej Stolicy Apostolskiej również w podejmowaniu i rozwiązywania szczegółowych problemów uchodźców i wypędzonych. Sekcja pierwsza „po porozumieniu z innymi kompetentnymi dykasteriami (...) troszczy się o sprawy obecności i działania Stolicy Świętej w instytucjach międzynarodowych (...). To samo czyni, gdy chodzi o międzynarodowe instytucje katolickie" 73 .

W tym kontekście należy podkreślić wielokierunkową i wielostronną aktywność organów dyplomatycznych Stolicy Apostolskiej tak wo-

${ }^{69}$ Tamże, art. 11 par. 2.

${ }^{70}$ PB 39.

${ }^{71}$ Tamże, art. 41 par. 1 . W ramach tej posługi sekcja pierwsza przygotowuje między innymi doroczne Orędzia Papieskie na Światowy Dzień Migranta i Uchodźcy.

${ }^{72}$ Tamże.

${ }^{73}$ Tamże, art. 42 par. 2. 
bec międzynarodowych organizacji rządowych jak i pozarządowych, szczególnie wówczas, gdy rozpatrywane są sytuacje konfliktowe, z natury swojej często generujące migrantów, uchodźców, wypędzonych i bezpaństwowców oraz tych, którzy poszukują poza swoją ojczyzną pracy i godziwych warunków życia.

Głównym zadaniem sekcji drugiej Sekretariatu Stanu Stolicy Apostolskiej, która powołana jest dla „relacji z państwami” jest „utrzymywanie kontaktów z przedstawicielami rządu"74. Zadanie to spełnia poprzez „1. podtrzymywanie stosunków dyplomatycznych z państwami oraz z innymi stowarzyszeniami prawa publicznego, jak również załatwianie wspólnych spraw, aby powiększało się dobro Kościoła i społeczności świeckiej. W razie potrzeby załatwia te sprawy z pomocą konkordatów oraz innych podobnych umów, biorąc pod uwagę opinie zainteresowanych konferencji biskupów; 2. W ramach międzynarodowych instytucji oraz spotkań działanie w imieniu Stolicy Świętej w sprawach o charakterze publicznym, po uzgodnieniu spraw z kompetentnymi dykasteriami Kurii Rzymskiej; 3. Podejmowanie w zakresie własnej kompetencji działań dotyczących papieskich legatów"75.

Sekcja druga Sekretariatu Stanu, podkreślając ważność polityki prowadzonej przez rządy poszczególnych krajów w relacjach bilateralnych jak i multilateralnych, w czasie różnego rodzaju zjazdów i kongresów może wskazywać na aktualne problemy migrantów oraz proponować sposoby ich rozwiązania, jak również uczestniczyć w pracach związanych z wypracowaniem polityki migracyjnej oraz wpływać na jej efekty końcowe dbając, by stanowione normy nie naruszały godności migrujących.

4.3. Specyfika zadań Kongregacji wobec migrujących

Kuria Rzymska, „przy pomocy której papież załatwia sprawy Kościoła powszechnego i która w jego imieniu oraz jego autorytetem wykonuje zadania dla dobra i służby Kościoła"76, jest organem wyko-

\footnotetext{
${ }^{74}$ Tamże, art. 45.

${ }^{75}$ Tamże, art. 48.

${ }^{76}$ KPK kan. 360.
} 
nawczym Stolicy Apostolskiej. Ona to poprzez poszczególne Kongregacje, przy zachowaniu ich kompetencji w różnych obszarach życia Kościoła, kieruje życiem duszpasterskim w ogólności, a także życiem duchowym migrantów i podróżnych.

Zderzenie kultur, rozumienie religii, zróżnicowanie ideologiczne, praktyki rytualne oraz różność zwyczajów itd., a więc to wszystko, z czym spotyka się przybysz w nowym miejscu zatrzymania i osiedlenia, może powodować, że jego wiara znajdzie się w pewnym kryzysie. Nowe warunki życia imigranta równocześnie stwarzają okazję do pogłębienia jego świadectwa wiary i ożywienia wrażliwości misyjnej wspólnoty przyjmującej. Katolicy krajów przyjmujących mogą również ze strony przybyszów otrzymać impulsy do ożywienia swojej wiary i praktyk religijnych, ale też spotkać się z duchowością niezgodną z doktryną Kościoła. Dlatego też Kongregacja Nauki Wiary, której zadaniem jest „troska o rozwój i strzeżenie nauki wiary i obyczajów"77 poprzez analizy i wypracowywane stanowiska zabiega, ażeby zjawisko migracji łączyło się ze wzrostem wiary, a na rodzące się pytania i wątpliwości była udzielana właściwa odpowiedź ${ }^{78}$. Kongregacja „wspiera biskupów, czy to pojedynczych, czy zgromadzonych na zebraniach, w wykonywaniu zadania, przez które stają się oni autentycznymi nauczycielami wiary i są zobowiązani do strzeżenia wiary i troski o jej rozwój" również w środowiskach przybyszów na terenie powierzonych diecezji ${ }^{79}$. W sposób szczególny czuwa ona, by w związku z ruchami migracyjnymi nie było przestępstw przeciw wierze i obyczajom jak oraz nadużyć w sprawowaniu sakramentów i ewentualnie wyjaśnia przyczyny ,zaciągnięcia sankcji kanonicznych lub przystępuje do ich nałożenia, zgodnie z prawem kanonicznym bądź też własnym"»0.

Fenomen migracji dotyka w sposób szczególny Kościoły wschodnie, które doświadczają wielkiej liczby wiernych emigrantów zrywających więź ze swoimi wspólnotami w nowym miejscu zatrzymania się

\footnotetext{
${ }^{77}$ PB 48.

${ }^{78}$ Tamże, art. 49.

${ }^{79}$ Tamże, art. 50.

${ }^{80}$ Tamże, art. 52.
} 
lub osiedlenia. Dlatego też Kongregacja dla Kościołów Wschodnich „obejmuje swoją troską wspólnoty wiernych wschodnich znajdujące się na terytorium Kościoła łacińskiego, zaradzając ich duchowym potrzebom przez wizytatorów, a gdzie liczba wiernych oraz okoliczności się tego domagają, również o ile to możliwe, przez własną hierarchię, uzgodniwszy sprawę z kongregacją kompetentną do erygowania Kościoła partykularnego na tym terenie" 81 .

Kongregacja ds. Kultu Bożego i Dyscypliny Sakramentów zajmuje się duszpasterstwem migrantów w kontekście inkulturacji liturgii, pomagając Kościołom partykularnym rozróżnić wartości kulturowe przynoszone przez imigrantów. Ona to wskazuje na te, które inkulturacji mogą być wprowadzone do liturgii. W ten sposób migranci katolicy mogą pielęgnować swoją kulturę celebracji liturgicznych i własną duchowość w nowym miejscu osiedlenia się i zamieszkania ${ }^{82}$.

Kongregacja ds. Biskupów, wśród wszystkich dykasterii Kurii rzymskiej jest historycznie pierwszą, która zajmowała się problemem migrantów i podróżnych. Powstała w jej strukturach Papieska Komisja Duszpasterstwa Migrantów i Turystów ${ }^{83}$, przekształcona została w konstytucji Pastor Bonus w obecną Papieską Radę ds. Duszpasterstwa Migrantów i Podróżujących. Kongregacja ta nadal zachowuje szczególnie ważną pozycję w obszarze duszpasterstwa ludzi w drodze, kiedy porządkuje i stymuluje oraz wspiera działania podejmowane przez biskupów ${ }^{84}$ oraz $\mathrm{w}$ razie potrzeby eryguje odpowiednie struktury Kościołów partykularnych lub dostosowuje je do aktualnych warunków duszpasterskich, uwzględniając przy tym potrzeby apostolatu na rzecz migrantów ${ }^{85}$. W tej perspektywie Papieska Komisja ds. Ameryki Łacińskiej, działająca w zależności od Kongregacji ds. Biskupów, której przewodniczącym jest każdorazowy prefekt Kongregacji, ma szczególne znaczenie w odpowiedzialności za migrujących. Komisja ma za zadanie świadczenie pomocy „Kościołom partykular-

\footnotetext{
${ }^{81}$ Tamże, art. 59.

${ }^{82}$ Por. KPK kan. 214; KKKW kan. 17.

${ }^{83}$ PAWEe VI, Motu proprio Apostolicae caritatis, AAS 62(1970), s. 193-197.

${ }^{84}$ PB 79.

${ }^{85}$ Tamże, art. 76.
} 
nym w Ameryce Łacińskiej, służąc radą, a także podejmując studium problemów dotyczących życia i rozwoju tych Kościołów"86. Zjawisko migracji z innych kontynentów do krajów Ameryki Łacińskiej, między poszczególnymi krajami Ameryki Łacińskiej oraz z krajów Ameryki Łacińskiej na inne kontynenty, rodzi przede wszystkim problemy przyjęcia przybyszów, ich integracji, respektu i poszanowania odrębności kulturowej i religijnej, ale także wzajemnego ubogacenia wartościami duchowymi.

Kongregacja ds. Ewangelizacji Narodów, do której należy „kierowanie i koordynowanie na całej kuli ziemskiej dzieła ewangelizacji narodów i współpracy misyjnej"87, w sposób szczególny włącza się $\mathrm{w}$ ewangelizację środowisk emigracyjnych poprzez troskę nie tylko o migrantów, często niewykwalifikowanych robotników, którzy emigrują z terenów misyjnych, ale również o tych, którzy na tereny misyjne przybywają z zamiarem zatrzymania się i osiedlenia. Zadaniem jej jest również ożywianie ducha misyjnego wśród migrujących, którzy poprzez świadectwo życia chrześcijańskiego mogą ewangelizować bądź reewangelizować środowiska i wspólnoty ich przyjmujące ${ }^{88}$. Kongregacja ds. Duchowieństwa włącza się w dzieło opieki Kościoła nad migrującymi gdy ,załatwia sprawy prezbiterów i diakonów duchowieństwa diecezjalnego, dotyczące czy to osób, czy pasterskiej posługi, czy też rzeczy, które są do ich dyspozycji w wykonywaniu tej posługi" ". Popiera ona również stałą formację osób duchownych ${ }^{90}$ oraz zabiega o formację religijną wiernych niezależnie od wieku i stanu poprzez katechezę, a także o przygotowanie katechetów. W ten sposób przygotowuje poszczególne wspólnoty wiernych do właściwego przyjęcia imigrantów, a mających zamiar emigrować do prowadzenia życia zgodnego z wiarą w warunkach emigracyjnych ${ }^{91}$. Kongregacja ds. Instytutów Życia Konsekrowanego i Stowarzyszeń Życia Apostol-

\footnotetext{
${ }^{86}$ Tamże, art. 83 par. 1.

${ }^{87}$ Tamże, art. 85.

${ }^{88}$ Tamże, art. 86-91.

${ }^{89}$ Tamże, art. 93.

${ }^{90}$ Tamże, art. 95 par. 3 .

${ }^{91}$ Tamże, art. 94.
} 
skiego podejmuje działania na polu apostolatu migrantów między innymi poprzez odnowę mentalności osób konsekrowanych otwierając ich na potrzeby duchowe migrujących i budowanie interkulturowych środowisk $^{92}$. Świadectwo życia wielokulturowych wspólnot życia konsekrowanego przyczynia się do kształtowania kultury przyjęcia tak wewnątrz instytutów, jak i wobec wiernych świeckich. Kongregacja mobilizuje również całe instytuty i stowarzyszenia oraz poszczególne osoby konsekrowane do włączania się w dzieło apostolatu migracyjnego $^{93}$. Kongregacja Seminariów i Instytucji Naukowych (Kongregacja Edukacji Katolickiej), ,wyraża i podejmuje troskę Stolicy Apostolskiej odnośnie do formacji tych, którzy mają otrzymać świecenia, jak również odnośnie do rozwoju i organizacji edukacji katolickiej"94. Ma ona zatem istotny wpływ także na tych, którzy w przyszłości będą spełniali opiekę duszpasterską nad migrantami oraz będą organizowali i kierowali tą specjalistyczną działalnością Kościoła.

4.4. Papieskie Rady a opieka nad poszczególnymi kategoriami migrantów

Papieska Rada ds. Świeckich jest „kompetentna we wszystkich sprawach należących do Stolicy Apostolskiej w zakresie popierania i koordynowania apostolstwa świeckich, oraz, ogólnie rzecz biorąc, we wszystkim, co dotyczy życia chrześcijańskiego świeckich jako takich"95. Tak zakreślony zakres kompetencji wskazuje, że liczne rzesze migrantów są nie tylko w zasięgu zainteresowań Rady, ale tworzą bezpośredni przedmiot jej zadań i odpowiedzialności. W tym kontekście trzeba przywołać również podlegające kompetencji Rady katolickie stowarzyszenia i ruchy wiernych świeckich, które rozwijają różnego rodzaju aktywność dla dobra migrantów, szczególnie na rzecz przyjęcia przybyszów i zabezpieczenia im poprawy warunków socjalnych. Zróżnicowanie wyznaniowe i religijne środowiska imigrantów jak i wspól-

\footnotetext{
${ }^{92}$ Tamże, art. 105.

${ }^{93}$ Por. EMCC 80-85.

${ }^{94}$ PB 112.

95 Tamże, art. 131.
} 
noty ich przyjmującej stwarza szczególne pole działania dla Papieskiej Rady ds. Popierania Jedności Chrześcijan. Zadaniem jej jest „podejmowanie, przez odpowiednie poczynania i działania, dzieła ekumenicznego dla przywrócenia jedności między chrześcijanami"96. Rada ta jest wspierana przez Papieską Radę ds. Dialogu Międzyreligijnego koordynującą ,kontakty z członkami i zespołami religii niechrześcijańskich oraz z tymi, którzy w jakikolwiek sposób kierują się zmysłem religijnym"97 oraz dla Papieskiej Komisji ds. Religijnych z Muzułmanami. Wielokulturowość środowiska migrantów stwarza również przestrzeń dla działalności Papieskiej Rady ds. Kultury ${ }^{98}$ oraz Papieskiej Rady ds. Środków Społecznego Przekazu. Ta ostatnia wspólnie z Sekretariatem Stanu ${ }^{99}$ dba, by dzięki środkom przekazu do przybyszów dotarły jak najszybciej właściwe i kompletne informacje o ich prawach i obowiązkach w miejscu zatrzymania się i zamieszkania, a także by Orędzie Zbawienia ,rozszerzało się (...) i dokonywał się ludzki postęp zmierzający do rozwoju kultury i obyczajów"100. Współczesne migracje w sposób szczególny dotykają małżeństwa i rodziny migrujących. Na mocy adhortacji apostolskiej Jana Pawła II Familiaris consortio z 1981 roku i Kartę Praw Rodziny ważną rolę w kompleksowej odpowiedzialności za migrujących odgrywa Papieska Rada ds. Rodziny, zabiegająca, aby również małżeństwo i rodzina migrantów mogły „,coraz lepiej wypełniać właściwe sobie zadania"101.

Również pozostałe dykasterie Kurii Rzymskiej na podstawie kompetencji wskazanych przez konstytucję Pastor Bonus włączają się w sposób mniej lub bardziej bezpośredni w troskę Kościoła o migrujących. Coraz częściej dojrzewa w Kościele rzymskokatolickim świadomość, że duszpasterstwo zwyczajne, oparte na terytorialnych zasadach, staje się duszpasterstwem migrantów, a „obcokrajowiec jest posłańcem Boga, który zaskakuje i rozrywa regularność i logikę co-

\footnotetext{
96 Tamże, art. 135.

${ }^{97}$ Tamże, art. 159.

${ }^{98}$ Tamże, art. 166.

99 Tamże, art. 169 par. 2.

100 Tamże, art.169 par. 1.

101 Tamże, art. 139.
} 
dziennego życia, przyprowadzając blisko kogoś dalekiego. W obcokrajowcach Kościół widzi Chrystusa, który «zamieszkał pośród nas» $(\mathrm{J}, 1,14)$ i który «kołacze do naszych drzwi» (Ap 3,20)"102.

\section{Zakończenie}

Współcześnie doświadczany wzrastający ruch migracyjny nie tylko stanowi wyzwanie dla poszczególnych państw i organizacji międzynarodowych, ale również dla Kościoła powszechnego i każdego z Kościołów partykularnych. Instrukcja Erga migrantes caritas Christi z 3 maja 2004 roku, wydana na podstawie zadań własnych ${ }^{103}$ przez Papieską Radę ds. Duszpasterstwa Migrantów i Podróżujących, daje „eklezjalną odpowiedź na nowe zapotrzebowania duszpasterskie migrantów, aby ich z kolei doprowadzić do przekształcenia doświadczenia migracyjnego w okazję nie tylko wzrastania w chrześcijańskim życiu, ale także nowej ewangelizacji i misji. Dokument zmierza również do dokładnego stosowania prawodawstwa zawartego w Kodeksie Prawa Kanonicznego z 1983 roku i Kodeksie Kanonów Kościołów Wschodnich, ażeby w bardziej adekwatny sposób odpowiedzieć również na potrzeby coraz liczniejszych emigrantów ze Wschodu"104 i jest wyrazem działania Papieskiej Rady ds. Duszpasterstwa Migrantów i Podróżujących, powołanej przez Jana Pawła II w konstytucji apostolskiej Pastor Bonus.

W kontekście przekazu soborowego dekretu o apostolstwie świeckich Apostolicam actuositatem o istotnej misji Kościoła, który „powstał po to, by poprzez rozszerzanie królestwa Chrystusa po całej ziemi ku chwale Boga Ojca uczynić wszystkich ludzi uczestnikami zbawczego odkupienia i by przez nie cały świat rzeczywiście został skierowany ku Chrystusowi"105, duszpasterstwo ludzi w drodze staje się zadaniem całej komunii Kościoła. Przesłanie Jana Pawła II w konstytucji Pastor

102 EMCC 101.

103 PB 149-151.

104 S. Hamao, Prezentacja, w: EMCC s. 5.

105 SobÓr WatYKaŃSKi II, Dekret o apostolstwie świeckich Apostolicam actuositatem, $\mathrm{nr} 2$. 
bonus odpowiadając na wyzwania migrujących, wskazuje nie tylko Papieskiej Radzie ds. Duszpasterstwa Migrantów i Podróżujących, ale i poszczególnym organom Stolicy Apostolskiej ich zadania, jakie w ramach powierzonej misji winni podejmować dla dobra wszystkich migrujących.

\section{The Roman Curia and spiritual welfare of migrants}

From its beginning, the Church offered pastoral care to all categories of migrants and itinerant people, as well as establishing responsibility for this specific action across all levels of her structure. John Paul II, in his apostolic constitution Pastor Bonus announced on the 28th June 1988, adjusted the work and structure of the Roman Curia to the actual pastoral needs of the Church. According to this document, all the issues concerning migrants are the specific responsibility of the Pontifical Council for the Pastoral Care for Migrants and Itinerant People. Reflecting on the various dicasteries it is necessary to note that as each of them undertake their particular responsibilities, they also play a role and participate in the apostolate for people who are on the move. 